\title{
Amino Acid Receptor Binding
}

National Cancer Institute

\section{Source}

National Cancer Institute. Amino Acid Receptor Binding. NCI Thesaurus. Code C40469.

A process that involves the binding of any member of the group of amino acid neurotransmitters, including glutamate, aspartate, serine, glycine and gammaaminobutyric acid, to their respective receptors. These interactions are involved in neurotransmission. 